\title{
A Decomposition Analysis of Capital Structure: Evidence from Pakistan's Manufacturing Sector
}

\author{
Attiya Yasmin Javid" and Qaisar Imad ${ }^{* *}$
}

\begin{abstract}
This study investigates the determinants of the various components of debt-short- and long-term debt and their categories-in the case of nonfinancial listed firms in Pakistan for the period 2008-10. We make a significant distinction between these determinants depending on the components of debt issued: long-term or short-term forms of debt. Our results show that large firms are more likely to have access to long-term debt borrowing than small firms and that, due to supply constraints, small firms resort to short-term forms of debt. Firms with higher potential for growth prefer using less long-term debt as well as debt with fewer restrictive arrangements in order to become more financially flexible. Firms with sufficient fixed assets can generate external finance more easily and at lower cost by using these assets as collateral, which supports the tradeoff theory. Firms generating high levels of profit, however, may choose to finance their investments using internal resources rather than by raising debt finance, which conforms to the pecking order theory. Our results also confirm the presence of the inertia effect and industry-specific effects, and are robust to alternative estimation techniques.
\end{abstract}

Keywords: Long-term debt, short-term debt, growth, firm size, profitability, Pakistan.

\section{JEL Classification: G32, G15, F23.}

\section{Introduction}

The behavior of corporations in making capital structure decisions is of considerable interest to financial economists. A firm's capital structure comprises different components of debt and equity-a mix of financing that maximizes returns and minimizes risk is known as an optimal capital structure. Capital structure policy, therefore, involves identifying the different factors that determine an optimal capital structure, and entails

\footnotetext{
* Professor of Economics, Pakistan Institute of Development Economics (PIDE), Islamabad, Pakistan.

*** Assistant Treasury Officer, Finance Department, Government of Khyber Pukhtunkhwa, Pakistan.
} 
making tradeoffs between risk and returns. High levels of debt financing may increase expected returns but they also carry a high risk of default on the repayment of debt.

Of the two schools of thought on capital structure, the first argues that there can be an optimal capital structure while the second, led by Modigliani and Miller (1958), argues the opposite. The first school holds that a firm can mix its debt and equity in a proportion that minimizes risk and maximizes the firm's returns and value. It proposes that firms should consider various factors when deciding on a specific capital structure, i.e., the relevance theory of capital structure. The second school supports the idea that different levels of capital structure offer the same level of risk and return, i.e., that capital structure does not matter and should not be considered as the firm's value is determined by its underlying investment decisions (Brealey \& Myers, 1996). The theory of the irrelevance of capital structure holds on the basis of certain assumptions, e.g., no transaction costs, no taxes, symmetric information, and no bankruptcy cost. When these assumptions do not hold, capital structure decisions become relevant in financing decisions.

Since Modigliani and Miller's (1958) influential study on the irrelevance of capital structure in investment decisions, a large body of theoretical literature has developed capital structure models under different assumptions. Some theories are based on traditional determinants such as tax advantage and the bankruptcy cost of debt, e.g., the tradeoff theory, while others apply modern financial economics and use an asymmetric information or game theory framework in which debt or equity is used as a signaling tool or strategy choice.

Theories that have been widely tested empirically include the tradeoff theory, pecking order theory, agency cost theory, and signaling information (for an excellent review of the literature on capital structure, see Frank \& Goyal, 2003; Harris \& Raviv, 1990). In addition, firms may find that the availability of external financing is restrictive and that the cost of different types of external finance may vary. Firms will try to select levels of debt and equity in order to reach an optimal capital structure in such an imperfect environment. However, there is little consensus on how firms select their capital structure, and the factors that influence components of capital structure are still largely unexplored.

Our main aim is to analyze the impact of selected factors-growth or investment opportunities, firm size, profitability, and tangibility-on the capital structure of firms listed on the Karachi Stock Exchange (KSE) (see 
Harris \& Raviv, 1990; Rajan \& Zingales, 1995). For a more in-depth analysis of the determinants of capital structure, we divide debt element into shortand long-term debt and their categories to indicate the sensitivity of the above factors to whichever debt component has been selected by the firm. While both short- and long-term debt components are used in corporate financial decisions, our analysis is based solely on long-term forms of debt, which provides a focused insight into the mechanics that operate Pakistan's financial and corporate sectors.

We attempt to provide empirical justifications for some of the theories on capital structure in Pakistan's context. In this regard, the study is an important contribution to the literature because it tries to identify the presence of the inertia effect in leverage decisions by applying dynamic panel models. We assess cross-industry differences in leverage choices by introducing industry dummies into leverage models. Above all, we investigate whether, in Pakistani firms, the determinants of the level of debt differ significantly depending on which element of debt is being examined.

The study is organized as follows. Section 2 reviews the empirical literature on capital structure. Section 3 discusses the methodology and data used. Our empirical results are presented in Section 4, and Section 5 concludes the study.

\section{A Review of the Literature}

This section reviews briefly several key theories of capital structure, and their results when empirically tested: (i) the pecking order theory, (ii) the static tradeoff hypothesis, and (iii) agency theory. It then summarizes some of the literature on the determinants of capital structure.

\subsection{Theories of Capital Structure}

The pecking order model tested by Myers and Majluf (1984) shows that the use of private information is the only source through which firm managers seek to issue risky and overpriced securities, as a result of which an outside investor will demand a higher rate of return on equity than on debt. Myers (1977) has argued that the pecking order model does not explain firms' dividends distribution. However, when firms choose to pay dividends for other reasons, pecking order choices should affect dividend decisions. This is explained by the argument that it is not desirable for firms to finance investment with new risky securities and dividends are less attractive for firms with less profitable assets with large current and future expected investments and high debt. However, if external financing 
becomes necessary when internally generated funds are not enough to pay dividends or to finance growth-oriented investment, the model hypothesizes that firms with a low risk of financial distress will issue direct conventional debt; firms with a medium risk of financial distress will issue hybrid securities—-such as convertible debt or preference shares; and firms that are high-risk due to financial distress will issue external equity.

The pecking order theory suggests that firms use a ranked structure to select sources of external financing (as mentioned above) only because the amount of mispricing and loss of wealth to shareholders both depend on the type of security issued. The amount of loss is lowest for debt and highest for external equity because new information affects the value of a security. The new information will have the least effect on the value of debt because debt holders have first priority on a firm's income and assets. However, new information will have the most effect on the value of equity because equity holders have a claim on the firm's residual income and assets.

Additionally, the pecking order theory postulates that debt increases when investment exceeds retained earnings and decreases otherwise. In this context, Fama and French (2002) empirically test and compare its hypothesis with that of the tradeoff model. Their results suggest that more profitable firms are less levered, which is consistent with the pecking order model. They also show that firms with greater investment opportunities are less levered, as postulated by the tradeoff theory. Myers (1977) suggests that, according to the pecking order theory, firms do not have debt targets; rather, their current and expected future financing costs set desired targets that can be modified. Firms expecting more investment opportunities may have less debt, but this may change over time when, for example, net cash flows are sucked up by debt.

The static tradeoff theory has been extensively tested empirically around the argument that the expected increase in tax-shield benefits from issuing debt finance may neutralize the cost of financial distress, such as cash flow volatility, the cost of expected bankruptcy in the case of default, and the threat of lack of cash. The theory suggests that the maximum debt is determined by equating the corporate tax-saving advantage of debt with the deadweight cost of bankruptcy (Barclay \& Smith, 1999; Bradley, Jarrell, \& Kim, 1984; DeAngelo \& Masulis, 1980; Myers, 1977). Miller (1977) and Graham and Harvey (2001) argue that the tax saving is large and sure while the bankruptcy cost seems to be very small, indicating that firms should have more debt compared to their leverage level. Further, Myers (1977) has argued that this theory should provide an important insight into optimum 
capital structure decisions in terms of tax shields, although he finds that the tax effects are very small when tested empirically.

From the standpoint of the static tradeoff theory, firms that are more profitable should issue more debt because they have more profits to protect from taxation. However, some studies have criticized this argument as higher profitability means lower expected costs of financial distress and, moreover, firms use more debt relative to book assets (Fama \& French, 2002; Myers, 1984; Titman \& Wessels; 1988). The tradeoff theory postulates that larger and more mature firms use more debt while managers are agents of shareholders and their interests may be in conflict with those of shareholders such that debt is considered a controlling device. Bankruptcy is costly for managers since they can be displaced and thus lose their job benefits. Therefore, debt can mitigate agency conflict between shareholders and managers, an idea put forward by Jensen and Meckling (1976), Jensen (1986), and Hart and Moore (1988). There may also be agency conflicts between shareholders and debt-holders (Myers, 1977).

Agency theory provides another explanation for why debt can be used as a controlling mechanism in agency costs between managers and shareholders-creditors may act as monitors of managers' investment decisions. However, these capital structure decisions do not necessarily control agency costs - the agency cost of debt comprises the problem of excessive dividends, issuance of senior ranking debt, asset substitution, and underinvestment (Smith \& Warner, 1979), which measure the possibility of bankruptcy and restructuring the debt and the cost of monitoring debt agreement. A firm with higher debt financing is more likely to have an agency cost of debt.

Firm managers are owners who try and transfer wealth from bondholders to shareholders; in this situation, the use of incentive contracts, such as options, is best suited to mitigating the problem. The empirical literature shows that the more profitable firms issue more debt to control managerial self-interest behavior. Agency theory suggests that growth firms should have less debt while firms that have more future profitable investment prospects need less debt. Regulated firms have fewer agency problems so that debt is not needed to discipline their management.

\subsection{Determinants of Capital Structure}

A large body of empirical research attempts to identify the most significant determinants of optimal structure but the findings differ due to 
variations in context and the components of capital structure that are considered. Rajan and Zingales (1995) analyze the capital structure of nonfinancial firms in the G-7 countries, and identify a positive relationship between tangibility and leverage; the market-to-book value and profitability are negatively related to debt. Bevan and Danbolt (2000) examine the capital structure of 822 British companies, and find a positive relationship between the market-to-book ratio and nonequity liabilities-tototal assets ratio, but a negative relationship between the book value of adjusted debt-to-adjusted capital ratio. The market-to-book ratio has no impact on the book values of total debt-to-total assets ratio and debt-tocapital ratio, while the market-to-book ratio has a significant negative relationship with all forms of the market values of capital structure. Bevan and Danbolt also find that firm size has a positive relationship with the book values of all forms of capital structure, while profitability and tangibility have a negative relationship with both the book and market values of all measures of capital structure. They conclude that tangibility has a significant positive relationship with the book and market values of debt-to-total asset ratio and adjusted debt-to-adjusted capital ratio, but no significant relationship with the debt-to-capital ratio.

The empirical literature on emerging markets shows that, as with developing markets, firm size has a mixed relationship with leverage. Oyesola (2007) and Chen (2004) conclude that firm size is positively related to total debt and short-term debt, but negatively related to longterm debt. Suhaila and Wan Mahmood (2008), Ramlall (2009), Chen (2004), and Baral (2004) find that there is a negative association between firm size and total debt, while Teker, Tasseven and Tukel (2009) show that firm size and the ratio of depreciation to operating profit has no relationship with capital structure.

Profitable firms do not rely much on external debt (Chen, 2004; Liu \& Ren, 2009; Oyesola, 2007) and vice versa, and firms with a high tangibility ratio can easily access debt by offering tangible securities to their creditors (Liu \& Ren, 2009; Oyesola, 2007; Suhaila \& Wan Mahmood, 2008). However, Ramlall (2009) and Teker, Tasseven, and Tukel (2009) put forward slightly different results, showing that profitability is positively related only to long-term liabilities and short-term loans, and negatively related to the other components of capital structure.

Tangibility impacts capital structure negatively in the case of total liabilities and short-term liabilities, whereas it affects tangibility positively in the case of long-term liabilities, long- and short-term leases, long- and short-term loans, and long-term debt. Serrasqueiro and Nunes 
(2008) find that tangibility is not a significant determinant of capital structure. The nondebt tax shield and dividends have a positive relationship with leverage (Oyesola, 2007); the nondebt tax shield is positively related to the short-term debt ratio but negatively related to the long-term debt ratio (Chen, 2004; Ramlall, 2009; Serrasqueiro \& Nunes, 2008; Suhaila \& Wan Mahmood, 2008). Growth opportunities have a weak relationship with capital structure (Liu \& Ren, 2009; Oyesola, 2007; Serrasqueiro \& Nunes, 2008; Suhaila \& Wan Mahmood, 2008), although Chen (2004) documents a positive relationship and Baral (2004) identifies a negative relationship between the two.

In analyzing other determinants of capital structure, Suhaila and Wan Mahmood (2008) find a negative relationship between the liquidity (quick ratio) and interest coverage ratio (the ratio of net income before taxes and dividends to interest expenses) and debt. However, there is a weak but statistically significant relationship between income variability and capital structure. Chen (2004) reports that the cost of financial distress as represented by a firm's earning volatility has a very weak relationship with capital structure. Baral (2004) concludes that business risk, the dividend payout ratio, debt service capacity, and degree of operating leverage, are minor contributors to leverage. Finally, Serrasqueiro and Nunes (2008) find that the level of risk is not a significant determinant of capital structure.

\subsection{Capital structure in the Pakistani firm context}

The research on the Pakistani market's capital structure is very limited. Ilyas (2005), Shah and Hijazi (2004), and Shah and Khan (2007) have examined the capital structure of nonfinancial firms listed on the KSE. Shah and Khan reveal the existence of a positive relationship between tangibility and capital structure. Firm growth and profitability are negative but not statistically significant contributors to capital structure, while firm size has a very weak and statistically insignificant impact on capital structure. In addition, earning volatility and nondebt tax shield have no relationship with capital structure. Shah and Hijazi show that tangibility has no impact on, but that firm size has a positive relationship with leverage while growth and profitability have a negative relationship.

Ilyas (2005) points out that firms' profitability has a negative relationship with leverage, as do size and growth. The study's results show that there is a positive relationship between the nondebt tax shield and leverage, but that this relationship and the degree of financial leverage has a negative relationship with capital structure. Rafiq, Iqbal, and Atiq (2008) 
investigate the determinants of capital structure for Pakistan's chemical sector for the period 1993-2004, and conclude that firm size, profitability, income variations, nondebt tax shield, and growth are the important determinants of capital structure in that sector.

Cheema, Bari, and Siddique (2003) summarize the country's corporate growth history, providing an overview of the ownership and state of the financial market and its dynamics. They highlight the salient features of the ownership structure of Pakistan's top 40 listed companies. The country's main companies are family-controlled business groups, followed by the state, and affiliates of multinational corporations (Cheema et al., 2003; Javid \& Iqbal, 2008, 2010). This concentration of ownership on one hand and underdevelopment of the financial market to provide external finance on the other pushes firms to rely on retained earnings or on borrowing from the informal sector (Javid \& Iqbal, 2007).

The energy and chemicals sector rely on issuing equity for external financing and on short-term debt. Booth, Aivazian, Demirgüç-Kunt, and Maksmivoc (2001) point out that the use of short-term financing is greater than that of long-term financing in developing countries (including in Pakistan). It would be interesting to find out whether or not different categories of debt are affected by different factors in the case of Pakistan's manufacturing sector.

\section{Methodology and Data}

Using panel data estimation techniques, this study investigates the determinants of capital structure and its components for 77 nonfinancial firms listed on the KSE for the period 2008-10. We extend the methodology suggested by Rajan and Zingales (1995), who highlight the contribution of four factors in determining debt decisions at the firm level (in their case, for G-7 countries using a cross-section analysis for 1991): (i) market-to-book ratio, firm size, profitability, and tangibility. Our study includes different components of leverage and examines the effect of these traditionally selected determinants on those components. This section describes the dataset, and discusses the rationale for the various dependent and independent variables used and the manner in which they are calculated.

\subsection{Data and Sample}

The data for this study has been taken from annual reports of nonfinancial firms listed on the KSE. The sample comprises 77 of the KSE's 
listed nonfinancial firms ${ }^{1}$ for the period 2008-2010. These firms have been selected based on the criteria that they are representative of each sector, and were active and continuously listed during the period of analysis. The firms' annual reports were retrieved from their official websites. The study has also used the Business Recorder's website for firms' average stock prices in order to calculate their market value.

This section describes the sets of dependent and explanatory variables and their construction, the selection of which draws on the theoretical literature on capital structure in financial economics and the empirical evidence discussed in Section 2 (see Bevan \& Danbolt, 2000; Harris \& Raviv, 1990; Rajan \& Zingales, 1995; Shah \& Hijazi, 2004).

\subsection{Dependent Variables}

The leverage or gearing ratio is defined as the debt-to-equity ratio. Alternative measures of leverage are determined by different firm-specific factors. To examine the sensitivity of the definition of the leverage variable, it is important, therefore, that this variable be constructed by alternative definitions of leverage suggested in the empirical literature (Rajan \& Zingales, 1995). Decomposing the individual firm's leverage would give more insight into the factors that influence the components of leverage and the extent of their influence in determining corporate financial structure. Thus, we decompose debt into four components at book value. ${ }^{2}$

Nonequity liabilities-to-total assets $\left(L V_{1}\right)$ is defined as the ratio of long-term debt (LTD) plus trade credit and equivalent (TTCE) to total assets $(T A) .^{3}$ This measure is used as a proxy for the firm's liquidation value. However, Rajan and Zingales (1995) argue that this measure may be somewhat inflated because trade credit and equivalent belong to financing transactions rather than assets.

\footnotetext{
${ }^{1}$ These firms constituted 80 percent of the KSE's market capitalization in 2007. Note that we have included nonfinancial firms because there is a difference between their capital structure and that of financial firms, and a combined analysis of both might not present a true picture.

${ }^{2}$ The debt-to-equity ratio based on book values reflects firms' past financial choices, whereas the ratio's market value indicates their future choices (Frank \& Goyal, 2003). Fama and French (2002) point out some inconsistencies arising from the use of two different debt ratios: they observe that both the pecking order theory and static tradeoff theory apply to the book value of the ratio, and there are doubts if the predictions can be extended to the debt market value.

${ }^{3}$ At book value, $\mathrm{DE}_{1}=(\mathrm{TD}+\mathrm{TTEC}) / \mathrm{TA}$.
} 
Debt-to-total assets $\left(L V_{2}\right)$ is the simple ratio of long-term debt at book value $(L T D)$ to total assets $(T A){ }^{4}$

Debt-to-capital $\left(L V_{3}\right)$ is obtained by dividing long-term debt (LTD) by capital, where capital is calculated as long-term debt plus equity capital and reserves $(E C R)$ and preference shares $(P S) .{ }^{5}$

Adjusted debt-to-adjusted capital $\left(L V_{4}\right)$ : This ratio is obtained by dividing adjusted debt by adjusted capital. Adjusted debt is calculated by deducting total cash and equivalents (TCE) and marketable securities (MS) from long-term debt. Similarly, the book value of adjusted debt is calculated as the book value of long-term debt and capital plus provision $(P R O V)$ and deferred taxation (DTAX) less intangible assets (INTANG). ${ }^{6}$

These four components of the debt-to-equity ratio capture the key elements of capital structure. Therefore, the study focuses on the above four measures of leverage and examines their determinants.

\subsection{Independent Variables}

Although the factors determining capital structure components can be controversial (see Harris \& Raviv, 1990; Titman \& Wessels, 1988), we follow Rajan and Zingales (1995) and adopt four independent variables that are traditionally considered key.

\subsubsection{Growth}

The market-to-book ratio is used to capture the growth opportunities that exist for the firm. A negative relationship is expected to exist between growth potential and the level of debt. This is consistent with the agency theory proposed by Jensen and Meckling (1976) and also with Myers's (1977) argument concerning information asymmetry, i.e., that firms with high levels of debt may have the possibility of not exercising care with good investment opportunities. Therefore, firms with large investment opportunities would likely have low debt-to-equity ratios. Moreover, as growth opportunities do not promise immediate revenue, firms may be unwilling to take on large contractual liabilities at the time.

\footnotetext{
${ }^{4} \mathrm{DE}_{2}=\mathrm{TD} / / \mathrm{TA}$

${ }^{5} \mathrm{DE}_{3}=\mathrm{TD} / /(\mathrm{TD}+\mathrm{TCR}+\mathrm{PS})$

${ }^{6} \mathrm{DE}_{4}=(\mathrm{TD}-\mathrm{TCE}-\mathrm{MS}) / /(\mathrm{TD}+\mathrm{ECR}+\mathrm{PS}+\mathrm{PROV}+\mathrm{DTAX}-\mathrm{INTANG})$
} 
Growth opportunities are, essentially, intangible and, therefore, may be considered limited collateral value or liquidation value to firms. Those with greater growth potential may not be interested in seeking debt or in finding additional debt-financing sources. However, the empirical evidence regarding the relationship between debt and growth opportunities is inconclusive. Many studies find a negative relationship between the two (see Barclay, Smith, \& Watts, 1995; Chung, 1993; Rafiq et al., 2008; Rajan \& Zingales, 1995; Shah \& Hijazi, 2004; Titman \& Wessels, 1988), which bears out the argument of Jensen and Meckling (1976) and Myers (1977), and is consistent with the view that firms with high levels of growth opportunity can be expected to have low levels of debt.

Kester (1986) does not find any evidence for the expected negative relationship between growth opportunities and debt decisions, while Delcoure (2007) and Rafiq et al. (2008) come up with a positive relationship between the growth and leverage. It is expected that firms with more growth opportunities have higher leverage. Based on this argument, our first hypothesis is:

There is a positive relationship between growth opportunities and leverage.

In this study, the market-to-book ratio is used as a measure for firms' growth opportunities or investment opportunities. ${ }^{7}$ The market-tobook ratio (growth) ratio is calculated as the book value of total assets less the book value of equity plus the market value of equity divided by the book value of total assets.

\subsubsection{Firm Size}

The logarithmic transformation of sales is used as a measure for firm size in the theoretical literature; there is no explanation to support how the size of the firm affects its debt decisions. The inconclusive relationship between size and debt may be accounted for by the nature of large firms who leave fewer chances to fail, making it possible to measure size as the logarithm of net sales, which, if inverted, can be used as the probability of bankruptcy (Rajan \& Zingales, 1995). Larger firms are more likely to have a credit rating and thus have available to them nonbank debt financing, which is usually unavailable to smaller firms. This would imply a positive relationship between firm size and leverage (Titman \& Wessels, 1988).

\footnotetext{
${ }^{7}$ Firms' growth opportunities are measured by different proxies in the empirical literature, e.g., the market-to-book value of equity, research-expenditure-to-total-sales measure, and annual percentage increase in total assets (Titman \& Wessels, 1988).
} 
The opposing view is that there is less asymmetric information about larger firms, reducing the chances of the undervaluation of new equity issues, and encouraging large firms to use equity financing. This means that there should be a negative relationship between size and leverage (Frank \& Goyal, 2003; Rajan \& Zingales, 1995). The empirical evidence with regard to the relationship between size and debt is inconclusive: Rajan and Zingales (1995), Bevan and Danbolt (2000), Shah and Hijazi (2004), and Rafiq et al. (2008) find firm size to be significantly and positively related to leverage. Size is expected to have a positive coefficient since larger, more diversified, firms are likely to have lower bankruptcy, and be able to sustain a higher level of debt (Agrawala \& Nagarajan, 1990; Ferri \& Jones 1979; Scott \& Martin, 1975). Larger firms are expected to have more leverage. This leads us to our second hypothesis:

There is a positive relationship between the size and leverage of a firm.

Firm size (size) is measured by taking the natural log of its sales.

\subsubsection{Profitability}

There are mixed opinions about a firm's profitability and its debt decisions. The supply-side argument suggests that the more profitable firms would have more debt available to them, and that the demand for debt is negatively associated with profitability. Stiglitz and Weiss (1981) argue that an information asymmetry prevents lenders from distinguishing between good and bad risks ex ante and that a variable interest rate cannot be charged depending on their risk type. In this case, creditors would charge an increased interest rate, which would generate the problem of adverse selection since low risks would quit the market due to the high cost of borrowing. Therefore, firms will tend to favor internal to external sources of finances due to this information asymmetry.

Modigliani and Miller (1963) suggest that, as taxes are paid after interest payments, firms may favor debt over equity, and the more profitable firms will select high levels of debt to gain more favorable tax shields. However, Miller (1977) has later criticized his and Modigliani's (1963) arguments by taking account of the effect of personal taxation. Moreover, DeAngelo and Masulis (1980) argue that some firms have other tax shields such as depreciation, and may not find interest tax shields as attractive.

The pecking order argument presented by Myers and Majluf (1984) and Myers (1984) is that information asymmetry pushes firms to favor internal over external capital sources, which is why firms that are more 
profitable will choose to finance investments through retained earnings rather than through external debt. Toy, Stonehill, Remmers, Wright, and Beekhuisen (1974), Kester (1986), Titman and Wessels (1988), Rajan and Zingales (1995), Tong and Green (2005), and Rafiq et al. (2008) also support the negative association between profitability and debt in line with the pecking order theory. Thus, the more profitable firms are expected to have less leverage. Our third hypothesis, therefore, is:

There is a negative relationship between the profits and leverage of a firm.

The firm's profitability (profit) is obtained by dividing its earnings before interest and taxes (EBIT) by its total assets.

\subsubsection{Tangibility of Assets}

The more fixed assets a firm owns, the better its chances are of easily obtaining external financing at a low cost since it can use these assets as collateral to secure debt (Rajan \& Zingales, 1995). Bradley et al. (1984), Titman and Wessels (1988), and Rajan and Zingales provide evidence of a positive relationship between debt and asset tangibility. The static tradeoff approach also suggests that firms with greater fixed assets can obtain more external debt by using these assets as collateral.

The pecking order theory, however, suggests that firms with low levels of fixed assets will also face problems of information asymmetry, pushing them to raise more debt rather than equity since they can only issue equity if it is underpriced (Harris \& Raviv, 1990). Contrary to this argument, large firms have greater fixed assets and are in a better position to issue equity at a fair price. Therefore, they do not need debt to finance new investment. It is expected that firms with a higher percentage of fixed assets will have higher debt ratios. Thus, our fourth hypothesis is:

There is a positive relationship between asset tangibility and firm leverage.

We measure tangibility as the ratio of fixed assets to total assets.

The determinants of leverage and its four components are described by equation (1) given below, which follows Rajan and Zingales (1995) and Bevan and Danbolt (2000).

$$
\text { Lev }_{i t}=\beta_{0}+\beta_{1} \text { Growth }_{i t}+\beta_{2} \text { Profit }_{i t}+\beta_{3} \text { Size }_{i t}+\beta_{4} \text { Tang }_{i t}+\varepsilon_{i t}
$$


$L E V_{i t}$ represents leverage or gearing ratio and various components of leverage, which are explained by the following factors: Growth (growth $\left.{ }_{i t}\right)$, size $\left(\right.$ size $\left._{i t}\right)$, profitability (profit $\left.t_{i t}\right)$, and tangibility (tang $\left.{ }_{i t}\right)$. These variables are measured on the basis of their book values taken from the sampled firms' financial statements.

\subsection{Estimation Technique}

In the first stage, we apply a panel data analysis technique to examine the extended leverage models, which will allow us to capture firm heterogeneity (if any) over time. Firm-specific effects are not taken into account in the pooled ordinary least squares (OLS) estimation. ${ }^{8}$ Making the empirical model a more general panel data equation and using the set of explanatory variables - growth, size, profitability, and tangibility-a more general, unrestricted, equation would be written as

$$
\text { Lev }_{i t}=\beta_{0}+\mu_{i}+\lambda_{t}+\beta_{1} \text { Growth }_{i t}+\beta_{2} \text { Profit }_{i t}+\beta_{3} \text { Size }_{i t}+\beta_{4} \text { Tang }_{i t}+\varepsilon_{i t}
$$

The intercept has three parts: $\beta_{0}$, which is common to all firms and all time periods; $\mu_{i}$, which represents firm-specific intercepts; and $\lambda_{t}$, which refers to time-specific intercepts. The term $\mu_{i}$ represents those unobservable effects that are specific to the firm but common to all time periods, $\lambda_{t}$ represents those effects that are specific to particular time periods but common to all firms, $\beta_{0}$ is the mean of all these unobservable effects, and $\varepsilon_{i t}$ is the error term representing all those unobservable effects that vary both over time and across cross-section units. The $\beta$ s are slope parameters, which we assume are constant over time as well as across firms and industries.

In the second stage, we estimate a series of dynamic panel leverage models to find out whether previous debt decisions affect firms' current debt choices. Finally, we introduce industry-specific dummies into the model to capture any cross-industry differences.

\section{Empirical Results}

Our panel data analysis estimates the determinants of four leverage components for 77 firms from 2008 to 2010. Table A1 in the Appendix gives summary statistics on the four components and four determinants of leverage, and the correlation matrix is presented in Table A2.

\footnotetext{
${ }^{8}$ Firm-specific effects are omitted under pooled OLS estimation. In such a case, if the unobservable individual-specific effects are correlated with the explanatory variables, then OLS estimates will be biased (Hsiao, 2003).
} 
Before carrying out the panel estimations, it is necessary to examine the data and choose an appropriate estimation technique. Important issues to address are whether the data is stationary or has a unit root; whether individual effects exist, or if the model should estimate a pooled equation with a common intercept and slopes. If there are individual effects, we need to determine if they are period-specific or cross-section-specific or both, and if the unobserved individual effects are fixed constant or randomly distributed independent of the explanatory variables. We also need to resolve any multicollinearity, autocorrelation, or heteroscedasticity.

The time period under study is short (three years) compared to the cross-section unit (77) so that a unit root test is not required. We begin by testing for individual effects and two-way fixed effects: Cross-section and time series are estimated first, followed by period-specific effects alone, cross-section-specific effects alone, and estimation with the application of a common intercept. The analysis consists of four models based on four components of leverage to investigate its determinants.

\subsection{Test for Data and Models}

To test for individual effects, the following three types of restrictions can be imposed on the above, unrestricted, specification of the models given in equation (2), i.e., to consider only time-specific effects and assume that there are no cross-section-specific effects and test the following hypothesis:

$$
H_{0}: \mu_{1}=\mu_{2}=\mu_{3}=\ldots=\mu_{N}=0
$$

If the F-test with $N-1$ and $N(T-1)-2 K$ degrees of freedom is significant, the null hypothesis will be rejected and we will have to estimate a model with cross-section-specific terms. The second restriction that can be imposed is to treat time-specific effects as equal to 0 , and consider a model with only cross-section-specific effects and test the following hypothesis:

$$
H_{0}: \lambda_{1}=\lambda_{2}=\lambda_{3}=\ldots=\lambda_{T}
$$

If the F-test with $T-1$ and $N(T-1)-2 K$ degrees of freedom is significant, the null hypothesis will be rejected and we will have to consider time-specific effects in our estimation model. However, if the F-statistic appears to be insignificant, then time-specific effects can be ignored. The final restriction is to treat the model as a common effects model with neither time- nor cross-section-specific effects and test the following hypothesis: 


$$
H_{0}: \mu_{1}=\mu_{2}=\mu_{3}=\ldots=\mu_{N}=0, \lambda_{1}=\lambda_{2}=\lambda_{3}=\ldots=\lambda_{T}=0
$$

If the F-test with $(N-1)+(T-1)$ and $N(T-1)-2 K$ degrees of freedom is significant, the null hypothesis can be rejected and the common effects model would be an incorrect choice.

In order to estimate individual effects, we first estimate two-way fixed effects followed by period-specific effects alone, cross-section-specific effects alone, and estimation with a common intercept. The results of the redundant fixed effects are presented in Table 1.

Table 1: Individual effects test

\begin{tabular}{lrrrl}
\hline Effects test & Statistic & \multicolumn{1}{c}{ d.f. } & Prob. & Conclusion \\
\hline Cross-section F-statistic & 63.13 & $(76,148)$ & 0.00 & Reject $H_{0}$ of redundancy \\
Period F-statistic & 6.46 & $(2,148)$ & 0.00 & Reject $H_{0}$ of redundancy \\
Cross-section/Period F & 61.61 & $(78,148)$ & 0.00 & Reject $H_{0}$ of redundancy \\
statistic & & & & \\
Cross-section F-statistic & 37.24 & $(76,148)$ & 0.00 & Reject $H_{0}$ of redundancy \\
Period F-statistic & 3.78 & $(2,148)$ & 0.00 & Reject $H_{0}$ of redundancy \\
Cross-section/period F & 36.59 & $(78,148)$ & 0.00 & Reject $H_{0}$ of redundancy \\
statistic & & & & \\
Cross-section F-statistic & 87.54 & $(76,148)$ & 0.00 & Reject $H_{0}$ of redundancy \\
Period F-statistic & 4.42 & $(2,148)$ & 0.00 & Reject $H_{0}$ of redundancy \\
Cross-section/period F & 85.54 & $(78,148)$ & 0.00 & Reject $H_{0}$ of redundancy \\
statistic & & & & \\
Cross-section F-statistic & 79.58 & $(76,148)$ & 0.00 & Reject $H_{0}$ of redundancy \\
Period F-statistic & 6.61 & $(2,148)$ & 0.00 & Reject $H_{0}$ of redundancy \\
Cross-section/period F & 77.76 & $(78,148)$ & 0.00 & Reject $H_{0}$ of redundancy \\
statistic & & & & \\
\hline
\end{tabular}

Source: Authors' calculations.

Both the F-test and the likelihood function (chi-square test) ${ }^{9}$ indicate the presence of cross-section fixed effects and period effects. Thereafter, separate tests are conducted. In one case, the unrestricted model is that with only cross-section fixed effects; in the second case, the unrestricted model is with only period effects. The results strongly suggest using a model with only cross-section effects and, therefore, we proceed with a model that has cross-section-specific but no period-specific effects.

\footnotetext{
${ }^{9}$ The chi-square tests (not reported here) also support the existence of cross-section-specific and time-specific effects.
} 
Having decided to estimate a model with cross-section-specific unobservable effects, our next task is to determine whether these effects are fixed constant correlated with the other explanatory variables (a fixed effects model) or randomly distributed independent of the explanatory variables (a random effects model). In this analysis, the cross-section units are larger than the time period, so care is taken when deciding between a fixed effects and random effects model. ${ }^{10}$

The Hausman (1978) test is used to choose between a fixed effects model and a random effects model. The null hypothesis of the Hausman test states that there is no significant difference between the coefficients of fixed and random effects estimators. ${ }^{11}$ Rejecting the null hypothesis would imply that at least some of the explanatory variables are correlated with the individual-specific effects. To perform the Hausman test, a random effects specification is estimated and the null hypothesis of independent individual effects tested using chi-square statistics. The results of this test are presented in Table 4, and indicate that the null hypothesis is rejected if the p-value is less than 0.05-we therefore estimate a fixed effects model. If the Hausman specification test had generated a p-value greater than 0.05 , then the null hypothesis would have been accepted, proposing that a random effects model was more suitable.

As regards multicollinearity, the results of the correlation matrix (Table A2 in the Appendix) indicate that the values of all the correlation coefficients between the model's explanatory variables are not very high. The coefficient covariance matrix given in Table A3 in the Appendix clearly indicates that there is no significant relation between the coefficients because the coefficient of covariance between most of the variables is small.

The White heteroscedasticity test is applied before final estimation to check for heteroscedasticity, first, by estimating a fixed effects model,

\footnotetext{
${ }^{10}$ With a finite time period and large cross-section units as in this analysis, there is much difference in the estimated parameters of fixed or random effects models compared to cases where the time series is large and the two models give approximately the same results (Hsiao, 2003).

${ }^{11}$ Fixed effects estimators are consistent if the cross-section-specific effects are correlated with the explanatory variables and the random effects are inconsistent and biased. But the random effects are consistent and the fixed effects are inconsistent if the individual-specific effects are independently and randomly distributed of the explanatory variables. Thus, the key factor to consider is whether or not the individual effects are correlated with the explanatory variables. The chi-square test for the difference in estimates is
}

$\chi_{d f}^{2}=\left(\hat{\beta}_{F E}-\hat{\beta}_{R E}\right)^{\prime}\left[\operatorname{var}\left(\hat{\beta}_{F E}\right)-\operatorname{var}\left(\hat{\beta}_{R E}\right)\right]^{-1}\left(\hat{\beta}_{F E}-\hat{\beta}_{R E}\right)$. 
and, then, using the results to reject the null hypothesis of homoscedasticity. Therefore, in the final estimation, the problem of heteroscedasticity will have to be taken into account by estimating the White heteroscedasticity of the adjusted covariance matrix.

\subsection{Results of Panel Data Analysis}

We begin the panel data analysis by examining the effects of four factors in determining the four types of components of leverage. The results for four simple leverage models given in equation (2) are presented in Table 2 below.

\section{Table 2: Determinants of capital structure components (fixed effects model)}

\begin{tabular}{lcccc}
\hline Variable & $\begin{array}{c}\text { Nonequity } \\
\text { liabilities-to- } \\
\text { total assets }\end{array}$ & $\begin{array}{c}\text { Debt-to-total } \\
\text { assets }\end{array}$ & $\begin{array}{c}\text { Debt-to- } \\
\text { capital }\end{array}$ & $\begin{array}{c}\text { Adjusted debt- } \\
\text { to-adjusted } \\
\text { capital }\end{array}$ \\
\cline { 2 - 5 } Growth & -0.03 & Model 2 & Model 3 & Model 4 \\
Size & $(-0.91)$ & $(-2.41)$ & $(-6.40)$ & 0.09 \\
& $0.11^{*}$ & $0.05^{*}$ & $0.05^{* *}$ & $0.73)$ \\
Profitability & $(8.45)$ & $(8.47)$ & $(1.88)$ & $(2.79)$ \\
& $-0.10^{*}$ & $-0.03^{* *}$ & $-0.10^{*}$ & $0.18^{*}$ \\
Tangibility & $(-15.05)$ & $(-3.05)$ & $(-2.54)$ & $(2.06)$ \\
& $0.52^{*}$ & $0.56^{*}$ & $0.56^{*}$ & $0.50^{*}$ \\
C & $(10.37)$ & $(15.31)$ & $(10.31)$ & $(5.48)$ \\
& $-0.52^{*}$ & $0.44^{*}$ & -0.20 & -0.03 \\
Hausman & $(2.39)$ & $(-3.46)$ & $(0.82)$ & $(-0.79)$ \\
(p-value) & 6.43 & 8.23 & 5.66 & 16.69 \\
$\mathrm{R}^{2}$ & $(0.15)$ & $(0.08)$ & $(0.03)$ & $(0.00)$ \\
\hline
\end{tabular}

Note: The covariance matrix is White heteroscedastic-adjusted; $t$-values are given in parentheses below coefficients. Asterisk(s) * and ${ }^{* *}$ indicate significance at 1 and 5 percent, respectively.

Source: Authors' calculations.

The results of the Hausman specification test in Table 2 indicate that the fixed effects model best fits the data in all categories of leverage. The regression results for the nonequity liabilities-to-total assets ratio show that growth opportunities are not related to short-term leverage. Profitability has a negative relationship with the nonequity liabilities-to-total assets ratio. Tangibility and firm size both have a strong, positive, and statistically 
significant relationship with the dependent variable. The results also imply that the more profitable firms use less debt, especially short-term trade credit, since this debt ratio is adjusted to short-term trade credit.

The results for the determinants of debt-to-total assets and debt-tocapital are similar: Growing and profitable firms have less leverage whereas larger firms with greater tangible assets use more debt. The adjusted debt-to-adjusted capital ratio has no relationship with growth opportunities, size, or profitability, while tangibility and size have a strong, positive relationship with this category of leverage. The adjusted debt-toadjusted capital ratio has a negative relationship with growth opportunities, size, and profitability, while tangibility and size have a strong positive relationship with the dependent variable.

The first hypothesis is not borne out by all the components of debt because growth opportunities are not positively linked to leverage. Earlier studies have also shown inconclusive evidence in this regard. Hijazi and Tariq (2006) and Rafiq et al. (2008) find a positive relationship between growth and leverage, whereas Shah and Hijazi (2004) find a negative relationship. The hypothesis that the more profitable firms use less leverage is confirmed by the first three categories of debt with the exception of the adjusted debt-to-adjusted capital ratio. This result provides empirical evidence in support of the pecking order hypothesisthat firms prefer to finance their operations through internal sources, followed by external debt and equity financing-and Shah and Hijazi (2004), Hijazi and Tariq (2006), and Rafiq et al. (2008) conclude the same.

The hypotheses that firm size and asset tangibility are positively associated with leverage are also confirmed by all components of debt. These results are in line with those of Jensen and Meckling (1976) and Myers (1977) whose tradeoff theory suggests that firms with greater fixed assets can use those assets as collateral and, therefore, issue more debt. Shah and Hijazi (2004) generate the same results. The firm size and leverage relationship is in line with the bankruptcy cost theory on leverage, i.e., that the fixed direct costs of bankruptcy constitute a smaller portion of the firm's total value and, thus, larger firms are willing to take on more debt because of the smaller chances of their going bankrupt. These results do not, however, confirm Rajan and Zingales's (1995) argument concerning less asymmetric information about large firms, suggesting that new equity issue will not be underpriced and that large firms will, therefore, issue more equity. 


\subsection{Results of Dynamic Panel Models}

In the second stage, we estimate a series of dynamic panel models for all four categories of leverage to examine the inertia effect on firms' debt choices (Table 3). Firms that previously relied more heavily on debt are thought to follow the same trend, and the lagged leverage term is added to the set of explanatory variables. The Hausman specification test confirms that the fixed effects model fits the data well in the case of all four models.

\section{Table 3: Determinants of capital structure components (dynamic panel model)}

\begin{tabular}{lcccc}
\hline Variable & $\begin{array}{c}\text { Nonequity } \\
\text { liabilities-to- } \\
\text { total assets }\end{array}$ & $\begin{array}{c}\text { Debt-to-total } \\
\text { assets }\end{array}$ & $\begin{array}{c}\text { Debt-to- } \\
\text { capital }\end{array}$ & $\begin{array}{c}\text { Adjusted debt- } \\
\text { to-adjusted } \\
\text { capital }\end{array}$ \\
\cline { 2 - 5 } Leverage (-1) & 0.75 & Model 2 & Model 3 & Model 4 \\
Growth & $(4.75)$ & $0.61^{*}$ & $0.83^{*}$ & $0.94^{*}$ \\
Size & -0.02 & $-0.01^{* * *}$ & $(11.48)$ & $(3.69)$ \\
& $(-1.21)$ & $(-1.66)$ & $(-3.08)$ & 0.09 \\
Profitability & $0.11^{*}$ & $0.04^{*}$ & $0.05^{*}$ & $0.16)$ \\
Tangibility & $(6.26)$ & $(3.63)$ & $(2.13)$ & $(2.71)$ \\
& $-0.10^{*}$ & $-0.10^{* *}$ & $-0.10^{*}$ & $-0.09^{*}$ \\
C & $(-2.27)$ & $(-1.88)$ & $(-2.02)$ & $(-2.56)$ \\
& $0.52^{*}$ & $0.24^{*}$ & $0.12^{*}$ & $0.25^{*}$ \\
Hausman & $(10.40)$ & $(11.42)$ & $(9.13)$ & $(2.72)$ \\
(p-value) & $-0.87^{*}$ & $-0.39^{*}$ & -0.20 & 0.31 \\
R $^{2}$ & $(-12.27)$ & $(-3.46)$ & $(0.95)$ & $(4.58)$ \\
\hline
\end{tabular}

Note: The covariance matrix is White heteroscedastic-adjusted; $t$-values are given in parentheses below coefficients. Asterisk(s) ${ }^{*}{ }^{* *}$, and ${ }^{* * *}$ indicate significance at 1,5 , and 10 percent, respectively.

Source: Authors' calculations.

Lagged leverage has a positive and statistically significant relationship with all categories of debt, confirming the presence of the inertia effect in firms' debt choices. The determinants follow the same pattern among all forms of debt as obtained from the ordinary panel analysis with fixed effects. Both firm size and tangibility have a positive 
relationship while profitability and growth opportunities have a negative relationship with the three components of debt; adjusted debt-to-adjusted capital shows no association between growth opportunities and leverage. These results show a clear distinction compared to long-term forms of debt and indicate that, for Pakistani firms, the determinants of the level of debt differ significantly depending on which element of debt is being examined.

\subsection{Results of Panel Model Using Industrial Dummies}

Since the Hausman specification test has confirmed the presence of fixed effects in cross-section units and no time-specific effects, we construct dummy variables to capture industry-specific effects for nine industries. These variables take a value of 1 for a particular industry and 0 otherwise. Of the nine industries, the tyres and wheels sector is used as a base category (D9). The remaining dummies are (i) D1 (oil and gas), (ii) D2 (chemicals and fertilizer), (iii) D3 (engineering), (iv) D4 (automobiles), (v) D5 (cement), (vi) D6 (paper and board), (vii) D7 (textiles), and (viii) D8 (refineries).

The results of this regression indicate that tangibility is positively and profitability negatively associated with leverage in all four forms, supporting the pecking order hypothesis. However, growth opportunities have a negative link with the first three components of debt and a positive relationship in the case of adjusted debt-to-adjusted capital. Size has a negative relationship with leverage when debt is defined as nonequity liabilities-to-total assets or debt-to-capital, and a positive relationship when it is defined as debt-to-total assets or adjusted debt-to-adjusted capital. The results of almost all the industrial dummies are significant, confirming the presence of individual effects in fixed form. These results indicate the robustness of the findings in that the traditional determinants play a role in debt decisions but are different among different components of debt.

Overall growth opportunities have a weak relationship with all components of capital structure except for the fourth component, i.e., adjusted debt-to-adjusted capital. The insignificant parameter on growth indicates that firms' growth opportunities have no impact on debt, which is contrary to expectations. Firm size has a positive and significant relationship with two components of capital structure, i.e., the long-term debt-to-total assets ratio and long-term debt-to-capital ratio; and a negative relationship with two other components, i.e., the nonequity liabilities-tototal assets ratio and adjusted debt-to-adjusted capital ratio. This result is consistent with the argument that larger firms have greater access to loans but, at the same time, require more financing for their operations. 
Table 4: Determinants of capital structure components (model with industrial dummies)

\begin{tabular}{|c|c|c|c|c|}
\hline & $\begin{array}{l}\text { Nonequity } \\
\text { liabilities-to- } \\
\text { total assets }\end{array}$ & $\begin{array}{l}\text { Debt-to-total } \\
\text { assets }\end{array}$ & $\begin{array}{c}\text { Debt-to- } \\
\text { capital }\end{array}$ & $\begin{array}{c}\text { Adjusted debt- } \\
\text { to-adjusted } \\
\text { capital }\end{array}$ \\
\hline Variable & Model 1 & Model 2 & Model 3 & Model 4 \\
\hline Growth & $\begin{array}{r}-0.07^{*} \\
(-11.52)\end{array}$ & $\begin{array}{r}-0.04^{*} \\
(-10.91)\end{array}$ & $\begin{array}{r}-0.20 \\
(-9.74)\end{array}$ & $\begin{array}{r}0.07 \\
(3.66)\end{array}$ \\
\hline Size & $\begin{array}{c}-0.11^{*} \\
(-4.61)\end{array}$ & $\begin{array}{c}0.04^{*} \\
(8.60)\end{array}$ & $\begin{array}{r}0.02^{*} \\
(-3.18)\end{array}$ & $\begin{array}{r}0.22^{*} \\
(10.87)\end{array}$ \\
\hline Profitability & $\begin{array}{c}-0.16^{*} \\
(-13.10)\end{array}$ & $\begin{array}{l}-0.15^{*} \\
(-5.15)\end{array}$ & $\begin{array}{l}-0.29^{*} \\
(-3.48)\end{array}$ & $\begin{array}{l}-0.30^{*} \\
(-4.98)\end{array}$ \\
\hline Tangibility & $\begin{array}{r}0.36^{*} \\
(16.89)\end{array}$ & $\begin{array}{r}0.53^{*} \\
(31.61)\end{array}$ & $\begin{array}{c}0.44^{*} \\
(8.70)\end{array}$ & $\begin{array}{c}0.06^{*} \\
(2.24)\end{array}$ \\
\hline D1 & $\begin{array}{r}0.04 \\
(0.03)\end{array}$ & $\begin{array}{r}0.17^{*} \\
(18.49)\end{array}$ & $\begin{array}{c}0.21^{*} \\
(7.00)\end{array}$ & $\begin{array}{r}-0.61 \\
(-6.35)\end{array}$ \\
\hline D2 & $\begin{array}{l}-0.21^{*} \\
(-3.88)\end{array}$ & $\begin{array}{c}0.05^{*} \\
(3.62)\end{array}$ & $\begin{array}{r}0.14^{*} \\
(11.74)\end{array}$ & $\begin{array}{l}-0.45^{*} \\
(-3.85)\end{array}$ \\
\hline D3 & $\begin{array}{c}-0.16^{*} \\
(-13.10)\end{array}$ & $\begin{array}{r}0.01 \\
(0.72)\end{array}$ & $\begin{array}{l}-0.10^{*} \\
(-2.02)\end{array}$ & $\begin{array}{r}-0.11 \\
(-0.85)\end{array}$ \\
\hline D4 & $\begin{array}{c}-0.15^{*} \\
(-2.71)\end{array}$ & $\begin{array}{r}0.02 \\
(0.68)\end{array}$ & $\begin{array}{c}0.38^{*} \\
(2.28)\end{array}$ & $\begin{array}{c}0.59^{*} \\
(5.31)\end{array}$ \\
\hline D5 & $\begin{array}{l}-0.27^{*} \\
(-5.62)\end{array}$ & $\begin{array}{l}-0.04^{*} \\
(2.43)\end{array}$ & $\begin{array}{c}0.07^{*} \\
(2.33)\end{array}$ & $\begin{array}{l}-0.48^{*} \\
(-4.01)\end{array}$ \\
\hline D6 & $\begin{array}{c}0.41^{*} \\
(9.00)\end{array}$ & $\begin{array}{l}-0.01 \\
(0.35)\end{array}$ & $\begin{array}{c}0.07^{*} \\
(7.57)\end{array}$ & $\begin{array}{l}-0.41^{*} \\
(-3.72)\end{array}$ \\
\hline D7 & $\begin{array}{l}-0.27^{*} \\
(-7.10)\end{array}$ & $\begin{array}{l}0.06^{*} \\
(2.34)\end{array}$ & $\begin{array}{r}0.11^{*} \\
(14.21)\end{array}$ & $\begin{array}{r}-0.15 \\
(-1.28)\end{array}$ \\
\hline D8 & $\begin{array}{c}0.38^{*} \\
(7.40)\end{array}$ & $\begin{array}{r}0.01 \\
(0.55)\end{array}$ & $\begin{array}{c}0.14^{*} \\
(7.21)\end{array}$ & $\begin{array}{r}0.34^{*} \\
(-2.31)\end{array}$ \\
\hline C & $\begin{array}{r}-0.48 \\
(-1.73)\end{array}$ & $\begin{array}{r}0.01 \\
(0.98)\end{array}$ & $\begin{array}{r}-0.10 \\
(-0.67)\end{array}$ & $\begin{array}{l}-1.26^{*} \\
(-4.36)\end{array}$ \\
\hline $\mathrm{R}^{2}$ & 0.62 & 0.64 & 0.30 & 0.34 \\
\hline
\end{tabular}

Notes: The covariance matrix is White heteroscedastic-adjusted; $\mathrm{t}$-values are given in parentheses below coefficients. Asterisk * indicates significance at 1 percent.

Industry dummies are introduced for nine sectors: D1 $=$ oil and gas, D2 $=$ chemicals and fertilizers, D3 = engineering, D4 = automobiles, D5 = cement, D6 = paper and board, D7 = textiles, D8 = refineries, and D9 = types and wheels. D9 is used as a reference category.

Source: Authors' calculations. 
Table 4's results identify a negative relationship between profitability and all the components of capital structure. This implies that high-profit firms prefer internal to external sources to finance their operations. This result is consistent with the pecking order hypothesis, which states that firms will finance their operations in a specific order of preference, i.e., internal sources, followed by external sources of financing. Our results also reveal that tangibility has a strong positive relationship with all components of capital structure, indicating that firms with greater fixed assets will have more access to short- and long-term loans since they can use those assets as collateral against loans.

Our analysis of these components of debt underscores the importance of considering both long- and short-term debt and their determinants as separate categories. Therefore, an analysis of the determinants of debt based on total liabilities does not clarify the significant differences between long- and short-term debt, as documented by Van der Wijst and Thurik (1993), Chittenden, Hall, and Hutchinson (1996), and Barclay and Smith (1999). Our results reveal that the determinants of the level of debt issued by nonfinancial KSE-listed firms vary significantly depending on which component of leverage is being analyzed. We find that firm size is positively related to long-term debt rather than short-term debt forms. The fact that small firms are found to borrow in the short term rather than in the long term may indicate that they are supply-restricted since they do not have access to long-term borrowing.

The parameters on all the other most disaggregated debt elements are insignificant, and the relationship between the adjusted debt-toadjusted capital ratio, trade credit and equivalents, and the market-tobook ratio is negative and significant. Therefore, firms with strong future growth opportunities will prefer to finance themselves using internal enterprise credit rather than through more formal means. This conforms to Barclay and Smith's (1999) observations, who suggest that, when looking for debt financing, firms with high levels of growth potential prefer short- to long-term debt, as well as debt with fewer restrictive agreements to allow them more financial flexibility. These results concerning the different categories of debt are consistent with the findings of Rajan and Zingales (1995) and Bevan and Danbolt (2000).

Adjusted debt-to-adjusted capital comprises mostly long-term debt components, whereas the nonequity liabilities-to-total assets measure includes elements of short-term liabilities, in particular trade credit, the major component of debt for the average KSE-listed nonfinancial firm. The 
decomposition results reveal that the positive relationship between the market-to-book ratio and the nonequity liabilities-to-total assets ratio is due to the short-term nature of this measure. This confirms the hypothesis that the significant differences between debt measures and their determinants imply that the expected theoretical relationships in corporate financing depend on which component of debt is under investigation. The results confirm the presence of the inertia effect in debt decisions. The significant industry dummies indicate that debt decisions depend on the sector being considered.

\section{Conclusion}

This study has analyzed capital structure in detail by carrying out panel data regressions for 77 nonfinancial firms for the period 2008-2010. We have examined four components of capital structure: the ratios of (i) nonequity liabilities to total assets, (ii) debt to total assets, (iii) debt to capital, and (iv) adjusted debt to adjusted capital. Growth opportunities have a weak relationship with two components of capital structure-the ratio of long-term debt to total assets and that of long-term debt to capital-while the ratio of nonequity liabilities to total assets has a positive relationship and that of adjusted debt to adjusted capital has a negative relationship with a firm's growth potential.

Firm size has a positive and significant relationship with the longterm debt-to-total assets ratio and long-term debt-to-capital ratio; and a negative relationship with the nonequity liabilities-to-total assets ratio and adjusted debt-to-adjusted capital ratio. This result can be justified with the argument that larger firms have greater access to loans but require more resources to finance their operations.

We have identified a negative relationship between profitability and all four components of capital structure, indicating that high-profit firms prefer to finance their operations through internal rather than external sources. This result is consistent with the pecking order theory, which postulates that firms arrange to finance their operations in a specific order of preference, i.e., initially through internal sources and then through external sources.

Reflecting Jensen and Meckling's (1976) and Myers' (1977) tradeoff theory, our study reveals that tangibility has a strong positive relationship with all components of capital structure. This result shows that firms with greater fixed assets will have more access to short- and 
long-term loans because they can use these fixed assets as collateral. Our main findings suggest that an analysis of debt based solely on long-term debt does not provide a clear understanding of how firms make financial decisions; a complete picture of the determinants of capital structure requires a more rigorous analysis of all forms of corporate debt. Our results confirm the presence of the inertia effect and industry-specific effects, and are robust to alternative estimation techniques. 


\section{References}

Agrawal, A., \& Nagarajan, N. (1990). Corporate capital structure, agency costs, and ownership control: The case of all-equity firms. Journal of Finance, 45(4), 1325-1331.

Baral, K. J. (2004). Determinants of capital structure: A case study of listed companies of Nepal. Journal of Nepalese Business Studies, 1(1), 1-13.

Barclay, M. J., \& Smith, C. W. (1999). The capital structure puzzle: Another look at the evidence. Journal of Applied Corporate Finance, 12(1), 8-20.

Barclay, M. J., Smith, C. W., \& Watts R. L. (1995). The determinants of corporate leverage and dividends policies. Journal of Applied Corporate Finance, 7(4), 4-19.

Bevan, A. A., \& Danbolt, J. (2000). Capital structure and its determinants in the United Kingdom: A decomposition analysis (Working Paper No. 2000/2). Glasgow, UK: University of Glasgow, Department of Accounting and Finance.

Black, F. (1976). The dividend puzzle. Journal of Portfolio Management, 2(2), $5-8$.

Booth, L., Aivazian, V., Demirgüç-Kunt, A., \& Maksmivoc, V. (2001). Capital structures in developing countries. Journal of Finance, 56, 87130.

Bradley, M., Jarrell, G. A., \& Kim, E. H. (1984). On the existence of an optimal capital structure: Theory and evidence. Journal of Finance, $39,857-878$.

Brealey, R. A., \& Myers, S. C. (1996). Principles of corporate finance (5 th $^{\text {ed.). }}$. New York, NY: McGraw-Hill.

Cheema, A., Bari, F., \& Siddique, O. (2003). Corporate governance in Pakistan: Ownership, control and the law. In F. Sobhan \& W. Werner (Eds.), A comparative analysis of corporate governance in South Asia: Charting a road map for Bangladesh. Dhaka: Bangladesh Enterprise Institute.

Chen, J. (2004). Determinants of capital structure of Chinese-listed companies. Journal of Business Research, 57(12), 1341-1351. 
Chittenden, F., Hall, G., \& Hutchinson, P. (1996). Small firm growth, access to capital markets and financial structure: Review of issues and an empirical investigation. Small Business Economics, 8(1), 59-67,

Chung, K. H. (1993). Asset characteristics and corporate debt policy: An empirical test. Journal of Business, Finance, and Accounting, 20(1), 8398.

DeAngelo, H., \& Masulis, R. W. (1980). Leverage and dividend irrelevancy under corporate and personal taxation. Journal of Finance, 35(2), 453464.

Delcoure, N. (2007). The determinants of capital structure in transitional economies. International Review of Economics and Finance, 16(2), 400415.

Fama, E. F., \& French, K. R. (2002). Testing tradeoff and pecking order predictions about dividends and debt. Review of Financial Studies, 15(1), 1-33.

Ferri, M., \& Jones, W. (1979). Determinants of financial structure: A new methodological approach. Journal of Finance, 34(3), 631-644.

Frank, M. Z., \& Goyal, V. K. (2003). Testing the pecking order theory of capital structure. Journal of Financial Economics, 67(2), 217-248.

Graham, J. R., \& Harvey, C. R. (2001). The theory and practice of corporate finance: Evidence from the field. Journal of Financial Economics, 60, 187-243.

Harris, M., \& Raviv, A. (1990). Capital structure and the informational role of debt. Journal of Finance, 45(2), 321-349.

Hart, O., \& Moore, J. (1988). Incomplete contracts and renegotiation. Econometrica, 56, 755-786.

Hausman, J. A. (1978). Specification tests in econometrics. Econometrica, 46(6), 1251-1271.

Hijazi, S. T., \& Tariq, Y. B. (2006). Determinants of capital structure: A case for Pakistani cement industry. Lahore Journal of Economics, 11(1), 6380. 
Hsiao, C. (2003). Analysis of panel data (2nd ed.). Cambridge, UK: Cambridge University Press.

Ilyas, J. (2005). The determinants of capital structure: Analysis of nonfinancial firms listed in Karachi stock exchange in Pakistan. Journal of Managerial Sciences, 2(2), 279-307.

Javid, A. Y., \& Iqbal, R. (2007). External financial resource management by listed Pakistani firms. Pakistan Development Review, 46(4, Pt. 2), 449464 .

Javid, A. Y., \& Iqbal, R. (2008). Ownership concentration, corporate governance and firm performance: Evidence from Pakistan. Pakistan Development Review, 47(4), 643-659.

Javid, A. Y., \& Iqbal, R. (2010). Corporate governance in Pakistan: Corporate valuation, ownership and financing (Working Paper No. 57). Islamabad: Pakistan Institute of Development Economics.

Jensen, M. (1986). Agency costs of free cash flow, corporate finance and takeovers. American Economic Review, 76, 323-339.

Jensen, M., \& Meckling, W. (1976). Theory of the firm: Managerial behavior, agency costs and ownership structure. Journal of Financial Economics, 3(4), 305-360.

Kester, C. W. (1986). Capital and ownership structure: A comparison of United States and Japanese manufacturing corporations. Financial Management, 15, 5-16.

Lui, Y., \& Ren, J. (2009). An empirical analysis on the capital structure of Chinese listed IT companies. International Journal of Business and Management, 4(8), 46-51.

Miller, M. H. (1977). Debt and taxes. Journal of Finance, 32(2), 261-275.

Modigliani, F., \& Miller, M. H. (1958). The cost of capital, corporate finance, and the theory of investment. American Economic Review, 48(3), 261297.

Modigliani, F., \& Miller, M. H. (1963). Corporate income taxes and the cost of capital: A correction. American Economic Review, 53, 433-443 
Myers, S. C. (1977). Determinants of corporate borrowing. Journal of Financial Economics, 5(2), 147-175.

Myers, S. C. (1984). The capital structure puzzle. Journal of Finance, 39, 575592.

Myers, S. C., \& Majluf, N. (1984). Corporate financing and investment decisions when firms have information investors do not have. Journal of Financial Economics, 13(2), 187-222.

Oyesola, S. R. (2007). An empirical analysis of the capital structure of selected quoted companies in Nigeria. International Journal of Applied Economics and Finance, 1(1), 16-28.

Rafiq, M., Iqbal, A., \& Atiq, M. (2008). The determinants of capital structure of the chemical industry in Pakistan. Lahore Journal of Economics, 13(1), 139-158.

Rajan, R., \& Zingales, L. (1995). What do we know about capital structure? Some evidence from international data. Journal of Finance, 50, 14211460 .

Ramlall, I. (2009). Determinants of capital structure among non-quoted Mauritian firms under specificity of leverage: Looking for a modified pecking order theory. International Research Journal of Finance and Economics, 31, 83-92.

Scott, D., \& Martin, J. (1975). Industry influence on financial structure. Financial Management, 4(1), 67-73.

Serrasqueiro, Z., \& Nunes, P. M. (2008). Determinants of capital structure: Comparison of empirical evidence from the use of different estimators. International Journal of Applied Economics, 5(1), 14-29.

Shah, A., \& Hijazi, S. T. (2004). The determinants of capital structure of stock exchange-listed non-financial firms in Pakistan. Pakistan Development Review, 43(4), 605-618.

Shah, A., \& Khan, S. (2007). Determinants of capital structure: Evidence from Pakistani panel data. International Review of Business Research Papers, 3(4), 265-282. 
Smith, C. W., \& Warner, J. B. (1979). On financial contracting: An analysis of bond covenants. Journal of Financial Economics, 7, 117-161.

Song, H.-S. (2005). Capital structure determinants: An empirical study of Swedish companies (Working Paper No. 25). Stockholm, Sweden: Royal Institute of Technology, Centre of Excellence for Science and Innovation Studies.

Stiglitz, J. E., \& Weiss, A. (1981). Credit rationing in markets with imperfect information. American Economic Review, 71(3), 393-410.

Suhaila, M. K., \& Wan Mahmood, W. M. (2008). Capital structure and firm characteristics: Some evidence from Malaysian companies (MPRA Paper No. 14616). Retrieved from Munich Personal RePEc Archive at (http://mpra.ub.uni-muenchen.de/14616/1/MPRA_paper_14616.pdf).

Teker, D., Tasseven, Ö., \& Tukel, A. (2009). Determinants of capital structure for Turkish firms: A panel data analysis. International Research Journal of Finance and Economics, 29, 179-187.

Titman, S., \& Wessels, R. (1988). The determinants of capital structure choice. Journal of Finance, 43(1), 1-19.

Tong, G., \& Green, J. C. (2005). Pecking order or trade-off hypothesis? Evidence on the capital structure of Chinese companies. Applied Economics, 37, 2179-2189.

Toy, N., Stonehill, A., Remmers, L., Wright, R., \& Beekhuisen, T. (1974). A comparative international study of growth, profitability and risk as determinants of corporate debt ratios in the manufacturing sector. Journal of Financial and Quantitative Analysis, 9(5), 875-886.

Van der Wijst, N., \& Thurik, R. (1993). Determinants of small firm debt ratios: An analysis of retail panel data. Small Business Economics, 5, 55-65. 


\section{Appendix}

Table A1: Summary statistics

\begin{tabular}{lccccc}
\hline \multicolumn{5}{c}{ Leverage } \\
\hline & Mean & Median & Stan. dev. & Skewness & Kurtosis \\
\hline Lev $_{1}$ & 0.38 & 0.33 & 0.27 & 3.65 & 23.99 \\
Lev $_{2}$ & 0.21 & 0.15 & 0.21 & 2.52 & 13.18 \\
Lev $_{3}$ & 0.35 & 0.26 & 0.32 & 2.48 & 13.77 \\
Lev $_{4}$ & 0.48 & 0.36 & 0.45 & 2.14 & 9.85 \\
\hline \multicolumn{5}{c}{ Explanatory variables } \\
Size & 9.61 & 9.55 & 0.75 & 0.15 & 3.11 \\
Growth & 1.51 & 1.33 & 0.81 & 1.57 & 5.71 \\
Profitability & 0.18 & 0.13 & 0.22 & 1.86 & 8.50 \\
Tangibility & 0.47 & 0.46 & 0.29 & 1.11 & 5.74 \\
\hline
\end{tabular}

Source: Authors' calculations.

Table A2: Correlations

\begin{tabular}{lcccccccc}
\hline & Lev $_{1}$ & Lev $_{\mathbf{2}}$ & Lev $_{\mathbf{3}}$ & Lev $_{\mathbf{4}}$ & Size & Growth & Profit. & Tang. \\
\hline Lev $_{1}$ & 1.000 & - & - & - & - & - & - & - \\
Lev $_{2}$ & 0.539 & 1.000 & - & - & - & - & - & - \\
Lev $_{3}$ & 0.325 & 0.556 & 1.000 & - & - & - & - & - \\
Lev $_{4}$ & 0.275 & 0.314 & 0.419 & 1.000 & - & - & - & - \\
Size & 0.233 & -0.117 & 0.026 & 0.205 & 1.000 & - & - & - \\
Growth & -0.021 & -0.152 & -0.105 & -0.053 & 0.103 & 1.000 & - & - \\
Profit. & -0.262 & -0.434 & -0.288 & -0.196 & 0.296 & 0.546 & 1.000 & - \\
Tang. & 0.129 & 0.619 & 0.542 & 0.073 & -0.161 & -0.030 & -0.175 & 1.000 \\
\hline
\end{tabular}

Source: Authors' calculations.

Table A3: Coefficients of covariance

\begin{tabular}{lcccccccc}
\hline & Lev $_{\mathbf{1}}$ & Lev $_{\mathbf{2}}$ & Lev $_{\mathbf{3}}$ & Lev $_{\mathbf{4}}$ & Size & Growth & Profit. & Tang. \\
\hline Lev $_{1}$ & 0.076 & 0.044 & 0.031 & 0.029 & 0.069 & -0.011 & -0.011 & 0.039 \\
Lev $_{2}$ & 0.044 & 0.044 & 0.040 & 0.003 & 0.004 & -0.028 & -0.013 & 0.044 \\
Lev $_{3}$ & 0.031 & 0.040 & 0.104 & 0.021 & -0.019 & -0.038 & -0.020 & 0.040 \\
Lev $_{4}$ & 0.029 & 0.003 & 0.021 & 0.204 & 0.095 & 0.014 & -0.014 & -0.014 \\
Size & 0.069 & 0.004 & -0.019 & 0.095 & 0.568 & 0.063 & 0.019 & -0.035 \\
Growth & -0.011 & -0.028 & -0.038 & 0.014 & 0.063 & 0.661 & 0.058 & -0.019 \\
Profit. & -0.011 & -0.013 & -0.020 & -0.014 & 0.019 & 0.058 & 0.050 & -0.011 \\
Tang. & 0.039 & 0.044 & 0.040 & -0.014 & -0.035 & -0.019 & -0.011 & 0.083 \\
\hline
\end{tabular}

Source: Authors' calculations. 